published as:

John Law \& Annemarie Mol, Situating technoscience: an inquiry into spatialities. in: Society and Space, 2001, vol 19, pp 609-621

\title{
SITUATING TECHNOSCIENCE: AN INQUIRY INTO SPATIALITIES*
}

\author{
John Law* and Annemarie Mol** \\ *Department of Sociology and \\ Centre for Science Studies, \\ Lancaster University, \\ Lancaster LA1, 4YN, UK \\ email: j.law@lancaster.ac.uk \\ ** Department of Philosophy, \\ University of Twente, \\ Postbus 217 \\ 7500 AE Enschede \\ The Netherlands \\ email: a.m.mol@gw.utwente.nl
}

\footnotetext{
${ }^{*}$ We are grateful to Michel Callon, Kevin Hetherington, Marianne de Laet, Bruno Latour, Vicky Singleton and Dick Willems for intellectual support and friendship. We are also grateful to Steve Hinchliffe, Doreen Massey, Steve Pile and other members of the Geography Discipline at the Open University for the chance to explore the arguments developed in this paper.
} 


\section{Down to Earth}

In the past one of the more remarkable characteristics attributed to scientific facts was their universality. Once established in a single place, their validity was supposed to transport itself everywhere, free of cost and without effort. But no. It is already far too place-oriented to put it like this. The faith in the universality of well established facts depended on never asking where-questions at all. The universal was, well, universal. Which meant that universalism didn't figure as a consequence of an attempt to add up, make links between, or otherwise relate various localities, but rather as something which transcended them.

Over the last decades something has changed in our understanding of the sciences. To summarise: facts have been localised.

Some context. The social studies of science are usually presented as a turn against the normativities of epistemology. While epistemologists were busy arguing about how science should proceed, social students of science went into laboratories and emerged with ethnographic stories about the ways in which science is actually practised. This shifted scholarly attention from the exigencies required of theory towards the textures of the practicalities of the laboratory. Labelling, marking, repeating, cleaning, numbering, noting, interpreting: these came to be known as the activities which compose science-in-action.

Thus, or so the overviews tell, idealist wishful thinking was overcome and the harsh realities of scientific life were faced. The point of the harshness not being that fraud and treachery were being perpetrated, but rather that the practice of science requires an enormous amount of laborious, meticulous, and routine manipulation of artefacts. Glamour disappears. Deference to science is no longer required. Epistemology has been defeated, or so the story goes. But, while this is not wrong, other things have been going on too. The process of tracking down 'science' in the laboratory rather than in theory not only implied that normative epistemology gave way to ethnographic realism. It also brought the sciences down to earth. No longer universal as a result of being transcendental, science needed to be localised.

But where? Where is science if it is not 'universal' - that is everywhere? This is the question we tackle in this article. It begins in a quite conventional way: we ask 'Where on earth?' But this is immediately followed by a second question: 'In what kind of space?' We take it to be urgent to address the question of the spatialities in which non-transcendentalisms may reside.

\section{$\underline{\text { Regions and Networks }}$}

Where on earth?

Perhaps the story starts with the laboratory studies of science, technology and society, in the late 1970s and the early 1980s. Where did these come from? The answer is that they were about science in practice rather than science in theory. Or, to put it a little differently, they were about how science is done, rather than engaging in normative epistemology. Which meant that those who did laboratory studies didn't hypothesise 
about which scientific method generates universal truth, or talk, as did Karl Popper, of a 'third world' beyond practice, where scientific ideas reside ${ }^{1}$. They didn't talk about 'the lab' as a general background to scientific knowledge. They didn't even locate theory and method in the specific culture of scientific communities - which was the importance of the work of Thomas $\mathrm{Kuhn}^{2}$. Instead they went to laboratories in the plural. And it was in this way that place first started to appear systematically in writing about science. Place appeared in relation to and reaction to the idea that science is non-localisable. Scientific method, theory, or findings as universal. Science was, as it were, brought down to earth. Bruno Latour went to see how scientific facts were constructed in the Salk Laboratory in San Diego. Karin KnorrCetina looked to see how they were made in an anonymous plant protein research site at Berkeley. Michael Lynch undertook more or less simultaneous fieldwork in a neuroscience laboratory, again in California. And others went as well ${ }^{3}$. Quite quickly the argument was made: scientific findings and theories are made in specific locations. They are always made somewhere. In a locality. They are regional, not universal.

But of course it was never quite as simple as that. Because scientific facts also travel between regions. Indeed, Bruno Latour and Steve Woolgar drew a diagram of the way facts and theories move around. They or the raw materials from which they are produced move around the laboratory. But they also move out of the front door of the laboratory and travel to other laboratories. From the Salk Institute to l'Institut Pasteur. For science is, to use the jargon, a global phenomenon. But how? How do they move?

It's possible to give a more or less straightforward empirical answer to this question. It has, for instance, to do with the postal system (or now, no doubt, the internet). Just as they depart from one laboratory, so they arrive at another. So post-rooms and the mail system are important. If science and its facts are not universal, then transport is crucial. But this answer, though it isn't wrong, hides a crucial complexity. For after universalism, the diffusion of science and its facts is not just a matter of physical transport. This is because facts are only facts if they are actually treated as facts when they arrive at their destinations. This means, or so the argument ran, that in most places the facts of science aren't recognised as such at all. They look like so many more or less meaningless pieces of paper. If they are to keep their status then something more is needed. They also have to be fitted into the local context - the next laboratory - in the right way. Which means that the configuration of facts-and-context has to be held stable.

Bruno Latour caught the issue in question when he asked how it is that the laws of Newton work just as well in the Gabon as in London ${ }^{4}$. And the answer is that it takes

\footnotetext{
${ }^{1}$ The term is explored by Popper at length in his (1972).

${ }^{2}$ See Kuhn's (1970).

${ }^{3}$ The studies cited are: Latour and Woolgar (1979); Knorr-Cetina (1981); and (Lynch 1985). Other more or less contemporary laboratory studies are cited in Lynch on pages xiii-xiv. Science was also being brought down to earth historically. Of particular importance in this context is Steven Shapin and Simon Schaffer's study of Robert Boyle and the air pump in seventeenth century Restoration England. See their (1985).

4 'We say that the laws of Newton may be found in Gabon and that this is quite remarkable since that is a long way from England. But I have seen Lepetit camemberts in the supermarkets of California. This is also quite remarkable, since Lisieux is a long way from Lose Angeles. Either there are two miracles
} 
effort, work, to maintain a stable configuration. It takes effort at each end (an experiment that works in a laboratory in London will only work in a laboratory in the Gabon if the configuration that produced it in London is reproduced, no doubt at great expense, in the Gabon). And it takes effort along the way, for whatever it is that moves between the two locations - a letter, an email - has to hold its shape, or there is no communication between the two.

This concern with transport and the work of holding configurations together and in shape - with so-called 'immutable mobiles' ${ }^{5}$ - was to lead to what became known as actor-network theory. And it also led to a concern not only with facts but also with technologies - for in science facts are almost always held in configurations that are in large part technological. Calibrating instruments and making sure that measures work - these kinds of activities are crucial in the work of making scientific facts. Thus it became important to understand how machines and machinations travel. So the concern with immutable mobiles and their relationship to the global was also explored for technologies themselves - as, for instance, in the mechanics of the Portuguese fifteenth and sixteenth century imperialism, and the ships on which this depended. Let's rehearse this argument ${ }^{6}$ : the question, then, is how do ships keep their shape?

Practically, the answer is that the vessels more or less held together as they moved from Lisbon to Calicut in India and back again. The actor-network analysis of this is that they did so, they were immutable mobiles, because a network was elaborated and performed, a network that sustained itself in a stable manner and did not budge. What was the nature of this network? The empirical answer is that it included hulls, spars, sails, winds, oceans, sailors, stores, navigators, stars, sextants, Ephemerides, guns, Arabs, spices and money - and a lot more besides. In this way of thinking, then, vessels become invariant and materially heterogeneous networks, immutable because the different components hold one another in place, at least in theory.

If we step back from this analysis we start to notice something that was not entirely clear when it was first laid out ${ }^{7}$. This is that the production of this network is a double production. On the one hand it generates an immutable mobile, a vessel that made it safely across the seven seas, an object holding itself together in a particular web of relations. But it also, and at the same time, implies a form of spatiality. The argument, then, is that a network-object also implies a stable shape within a network space. The two go together. Spatiality is an aspect of network stability. A large network (with its winds, its stars, its merchants and its princes) implies a network space which renders possible the immutable mobility of an object - such as a Portuguese ship travelling from Lisbon to Calicut.

Here it is possible to think topologically. Topology is a branch of mathematics which imagines different kinds of space. In particular, it invents spaces by thinking up different rules for defining the circumstances in which shapes will change their form

\footnotetext{
that have to be admired, or there are none.' Latour (1988), page 227.

${ }^{5}$ See Latour (1987).

${ }^{6}$ The case derives from John Law (1986).

${ }^{7}$ We are grateful to Kevin Hetherington for discussion on this and related points. For his relevant publications see, inter alia, Hetherington (1997; 1999; 2000; 2000). See also the work of David Turnbull (1993; 2000) and Helen Verran (1998), both of which explore the relationships between transport, regions, cartography and dominant knowledge traditions.
} 
or not. It is possible to devise indefinitely many rules for shape invariance, but in the case of the immutable mobile we are dealing with just two forms of spatiality: space as Euclidean; and space as a network. In Cartesian, regional or Euclidean space place is defined by a set of relative three-dimensional co-ordinates. So long as a ship is tied up in the harbour in Lisbon it does not move. And as soon as it sets out to sea, it displaces itself. But the space implied in actor-network theory is different. Is there no change in the working relations between the hull, the spars, the sails, the sailors and all the rest? If this is the case then the ship is immutable in the sense intended by Latour. It does not move in relation to a network space.

In fact to talk about 'immutable mobility' is to play a double game. We have been talking about immutability. Now we need to attend to the mobility part of the equation. Notice this. In network space there is nothing mobile about the vessel. It holds its shape. But it also holds its position in that space. It does not displace itself. It is an immutable immobile. Everything stays in place: the relations are sustained in a stable manner. The mobility of the Portuguese ships only exists in Euclidean Space. There they move through an orthogonal box defined by X-Y-Z co-ordinates - a box in which there is a long distance between Lisbon and Calicut.

Put this way, then, we find that the immutable mobile achieves its character by virtue of participation in two spaces: it participates in both network and Euclidean space. And such is Latour's trick. To talk of an 'immutable mobile' is to elide the two. The immutability belongs to network space: to a first approximation the vessel doesn't move within this. If it did, it would stop being a vessel. But it is that immutability in network space which affords the mobility in Euclidean space. To put it more strongly, it is the interference between the spatial systems that affords the vessel its special properties. We are in the presence of two topological systems, two ways of performing space. And the two are being linked together ${ }^{8}$.

So actor-network theory exposes similarity and difference within two forms of spatiality - while attending to the interference between the two ${ }^{9}$. But, as its critics have observed, the approach also has its inconveniences. First, though it is hardly the fault of actor-network theory, the notion of 'network' is so common that it is being denuded of much of its specificity ${ }^{10}$ and is in danger of becoming hegemonic ${ }^{11}$. Second, in its earlier versions actor-network theory tended towards a functional managerialism $^{12}$ : Bruno Latour is surely right to say that it would be better to talk of

\footnotetext{
${ }^{8}$ The notion of interference, drawn from its scientific roots in wave diffraction, is explored by Donna Haraway in her $(1996 ; 1997)$.

${ }^{9}$ This helps to undermine the essentialism of Euclidean space, but also hints at the way in which Euclidean space is produced. Something that is, in other ways, also considered in the writing of Marilyn Strathern or, very differently, of David Harvey, or Nigel Thrift, or Edward W. Soja, or then again Doreen Massey. See Strathern (1991), Harvey (1989), Thrift (1996), Soja (1989) and Massey (1994). Perhaps, however, the pioneer is Yves Lacoste in his sharp analysis of the shift from regions to network. See Lacoste (1976).

${ }^{10}$ It is true that most accounts of the so-called 'network society' have little to do with actor-network theory. We think, for instance, of Manuel Castells' recent and immensely popular writing. See Castells (1996). And also of Scott Lash and John Urry (1994).

${ }^{11}$ Marilyn Strathern has made an argument like this. See Strathern (1996).

${ }^{12}$ A point which scarcely applies to the 'ANT and after' writings which have appeared more recently. For a recent collection see Law and Hassard (1999).
} 
'actant-rhizomes ${ }^{, 13}$. In this looser locution it is relationality that becomes important the possibility of thinking in terms of (broadened) forms of connection - rather than the network metaphor which links an appreciation of relationality to a specific image of connectivity ${ }^{14}$. More complicated visions of spatiality are required ${ }^{15}$. The challenge, then, is to inquire into the possibility of other, non-Euclidean, nonnetwork, spatialities.

\section{Fluid Space}

So what are the possibilities? Fluid spatiality is one of these. Once again we return to the literature.

A study by Marianne de Laet and one of the present authors explores a fluid form of spatiality for the case of the Zimbabwe bush pump ${ }^{16}$. Look upon this pump not as something that moves within a network. Think of it instead as an Other to the network and its spatialities, something outside a network. And note then that the pump is a success which (to do the ethnography very quickly) spreads far and wide in Zimbabwe, into many of the villages that need a new water pump. So why is this? The answer is: because it changes shape. Of this pump and everything that allows it to work, nothing in particular necessarily holds in place. Bits break off the device and are replaced with bits which don't seem to fit. And other components - we're talking here both of parts of the 'machine itself', and the social relationsembedded in it - are added to it, components which were not in the original design itself.

Within Euclidean and network space alike, the bush pump is an object that changes shape. It looks different from one village to the next, and it works differently from one set-up to the next. Thus one might describe it as a failed network. Remember that the network comes with configurational invariance. But the bush pump shows configurational variance. It is a mutable mobile. Is it the same in two places? A network analyst would say no. And yet it makes sense to say that it is 'the same pump'. It is the 'Zimbabwe bush pump' that moves to so many places in rural Zimbabwe and that moves (so runs the argument) precisely because it is not an invariant shape either in network or in Euclidean space. It changes. It is different.

The 'inventor' of the pump talks happily about the variability of the artefact ${ }^{17}$. He reports that sometimes he comes to places where the pump has been installed, to discover variations in its installation which he had not thought of himself. And yet the pump still works. But beware. The mutability of the bush pump also extends to what it is for the pump to work. For instance (an apparent constant) the pump works if it

\footnotetext{
${ }^{13}$ See Latour (1999).

${ }^{14}$ Though even relationality performs certain possibilities, as Marilyn Strathern has noted. See her (1996).

${ }^{15}$ For this argument developed in the context of debates about the enactment of realities - that is as an aspect of ontology - see Annemarie Mol (1995).

16 The references are Annemarie Mol and John Law (1994) where the metaphor of the fluid is mobilised to talk about the diagnosis of anemia in both 'Africa' and the Netherlands; and Marianne de Laet and Annemarie Mol (2000).

${ }^{17}$ We put 'inventor' in citation marks because the person to whom it is often attributed denies authorship, arguing that the pump is a collective effort.
} 
produces clean water. But, what counts as clean water? This, it turns out, is highly variable. And this is not just a clever point of theory. There are international bacteriological definitions of cleanliness - a very limited number of that indicator bacterium, E.coli, per litre of water. Water from some of the bush pumps always meets these criteria, but only some. Others fail. And yet others, in fact the great majority in a country where the networks of laboratory testing are not well developed, simply aren't tested at all. But does this mean that the pumps fail? The answer is, not necessarily. If the level of water-borne disease is low then this comes to count as a functional definition of success. It turns out, then, that what counts as working is, itself, variable. The more so where the bush pump is not only an artefact that produces clean water. It is also an element of the rural policy of the Zimbabwean government. It is a way of encouraging collective action by village dwellers. And then again, it is active in constituting Zimbabwe as a nation to which the villages and the villagers belong. And the question of the pump's workings in both these additional contexts is again open to the variations of fluidity.

The conclusion, then, is that it misses the point to think of the bush pump as an object constituted within a failing network. Instead it is more useful to think of it as a fluid object, one that flows. And one that retains its shape as it flows, in different network configurations, into different Euclidean locations in (and beyond) Zimbabwe.

Here then, we discover a third topological system, a third version of space. Call it fluid spatiality. So what defines shape invariance in a fluid topology? No doubt there are various ways of thinking about this. However, one particular feature is crucial. This is that while the connections which make a shape invariant in fluid space change shape, they do so gradually and incrementally ${ }^{18}$. We said this above: links slowly change their character. From time to time bits, so to speak, fall off. New bits are patched on. This pump isn't quite like that pump. That pump is not quite like the other. This one functions in this way. That one functions somewhat differently. So the associations or forms of attachment shift and move, but they do so in a way that also allows the performance of continuity. The metaphor, then, is like Wittgenstein's notion of family resemblance. There is a sameness, a shape constancy, which does not depend on any particular defining feature or relationship, but rather on the existence of many instances which overlap with one another partially ${ }^{19}$.

So there are no great breaks or disruptions. Instead there is a process of gradual

\footnotetext{
${ }^{18}$ Notice that here as elsewhere we introduce temporality. The need to grapple with the fact that changes are quicker or slower: itself, to be sure, a difference given not in the order of things, but rather in performance. Times and spaces, it appears, are performed together. This is an issue of great importance that has attracted many social theorists and geographers, and one which perhaps reveals that spatialities are to be sensed only in relation to one another. Thus Tim Ingold's notion of the 'timescape' (1993) resonates with Michel Serres' observation, to which we will return: 'Les objets sont des flammes gelées par des temps différents. Mon corps est une flamme un peu plus lente que ce rideau qui consume les bûches. D’autres choses sont plus lentes encore, pierres, d'autre plus foudroyantes, soleils. Mille temps font battre leurs bords.' (Serres (1980), page 53). Or (our translation): 'Objects are flames frozen by different times. My body is a flame slightly slower than the curtain which consumes those logs. Others, stones, are still slower while yet others are so much faster - suns. A thousand times make their edges beat.'

${ }^{19}$ As Marilyn Strathern has noted, there are disadvantages to this metaphor with its commitment to smaller but invariant parts (facial features, genes).
} 
adaptation $^{20}$. Shape invariance is secured in a fluid topology in a process of more or less gentle flow. It is secured by displacement which holds enough constant for long enough, which resists rupture. A topology of fluidity resonates with a world in which shape continuity precisely demands gradual change: a world in which invariance is likely to lead to rupture, difference, and distance. In which the attempt to hold relations constant is likely to erode continuity. To lead to death ${ }^{21}$.

This is why the 'inventor' of the bush pump is unconcerned with standardisation. He has not sought to impose the rigidities of a patent. He is not bothered when those who install and use the pump introduce alterations. Indeed, on the contrary, he is interested and pleased. The pump, he says, does not belong to him. His idea is that it was invented by many, and in many different locations. This means that it goes on growing, changing, adapting, and working in places where it would never work if its relations were held stable, as in a network. And it also means that the 'inventor' performs fluidity himself. He contributes to enacting the fluid space within which the pump achieves shape constancy.

This is crucial, both empirically and theoretically. Empirically it is one of the sources of the success of the pump - and of the increase in clean water for the villagers of Zimbabwe. Theoretically, fluidity suggests a way of letting go, instead of holding onto, the rigidities of network. This is not a good in and of itself. There is, if we might put it this way, a place for network space, for configurational immutability. But only a place: it need not be a general model of shape-invariance. Fluid spatiality suggests that varying configurations, rather than representing breakdown and failure, may also help to strengthen objects. In this version of space shapes may start to vary where rigidities set a limit to flow. Or, alternatively, where change is too fast, too abrupt. Or in other ways again: for fluid spatiality deserves further exploration - along with its interferences with other spatial forms.

\section{Fire Space}

If water is the element of flow, then (at any rate in some of its versions) fire is the element of passion, action, energy, spirit, will and anger, not to mention creative destruction and sexuality. Philosopher of science Gaston Bachelard, wrestling frantically with his ambivalent desire to break with what he took to be the prescientific, talked (in what he called the Empedocles Complex) of the creative renewal of death implied by fire:

'The fascinated individual hears the call of the funeral pyre. For him destruction is more than a change, it is a renewal. ${ }^{22}$

\footnotetext{
${ }^{20}$ The suggestion is that the pump is a phenomenon quite unlike that of the flowing widely discussed in the literatures on globalisation (which are often better understood as the displacement of immutable mobiles within networks). For interesting additional commentary on this see John Urry (2000) and Mimi Sheller (2000).

${ }^{21}$ This is a trope which perhaps appears more often in the literatures on (inter)personal or organisational growth than it does in thinking about material objects, but is equally applicable to the latter.

${ }^{22}$ From Gaston Bachelard (1964), page 13.
} 
'Love, death and fire', (he adds on page 17), 'are united at the same moment'. And, he adds, they are united in reverie, the reverie of the person who stares at the flames in a fire:

'... the reverie is entirely different from the dream by the very fact that it is always more or less centred upon one object. The dream proceeds on its way in linear fashion, forgetting its original path as it hastens along. The reverie works in a star pattern. It returns to its center to shoot out new beams. ${ }^{23}$

What might we make of this? In the present context we want to pick out three possibilities.

First, and risking oxymoron, we want to treat the call of the funeral pyre, the trope of death and rebirth, as a metaphor for treating the continuity of shape as an effect of discontinuity. As with fluid constancy, movement rather than stasis is crucial. Without movement there is no consistency. The difference is that while in fluidity constancy depends on gradual change, in a topology of fire constancy is produced in abrupt and discontinuous movements.

Second, we want to treat Bachelard's observation as a call for attending to discontinuous transformation as a flickering relation between presence and absence. For Bachelard presence is life and absence death, but we don't have to follow him in this particular direction. Instead we might simply say that fire is a metaphor for thinking about the dependence of that which cannot be made present - that which is absent - on that which is indeed present. Or, as the post-structuralist literatures sometimes put it, the way in which the authority of presence depends on the alterity of Otherness.

Topologically, then, our argument is that in fire space a shape achieves constancy in a relation between presence and absence: the constancy of object presence depends on simultaneous absence or alterity. A flicker, an oscillation, an impossibility that is also a necessity: no doubt there are plenty of other possible metaphors.

Third, we also want to reflect on Bachelard's observation about the 'star pattern' of reverie. This evokes a specific version of the relation between presence and absence: a link between a single present centre and multiple absent Others. Our suggestion, then, is that one version (only one version) of shape constancy in the space of fire is that of a relatively stable set of star-like enactments between a single present and multiple absences ${ }^{24}$.

Three attributes: continuity as an effect of discontinuity; continuity as the presence and the absence of Otherness; and (for particular cases) continuity as an effect of a star like pattern in this simultaneous absence and presence: this is what we imagine as the attributes of shape constancy in a topology of fire. Thus fire becomes a spatial formation alongside (and in interference with) Euclidean, network and fluid spaces. To say that there is a fire topology is to say that there are stable shapes created in patterns of relations of conjoined alterity.

\footnotetext{
${ }^{23}$ From Gaston Bachelard (1964), page 14.

24 'One version', because we take it that this is a special case.
} 
To give this statement some flesh we'll take a technical example. It is a formalism. Consider the following:

$$
\mathrm{G}=\frac{\text { (velocity } \times \text { lift slope) }}{\text { wing loading }}=\frac{\text { M.at }}{\mathrm{W} / \mathrm{S}}
$$

This is an aerodynamic expression, a formalism used by a team of aircraft designers in the 1950s as they wrestled with the design for an aircraft wing - a wing that would be appropriate for a light bomber ${ }^{26}$. Their particular problem, and the issue addressed by the formalism, has to do with 'gust response'. Gust response is what air passengers sometimes experience as 'turbulence'. That is, it is a way of talking about the extent to which the wing of an aircraft passing through vertical gusts is buffeted . In this expression ' $G$ ' stands for gust response, and the higher the value for ' $G$ ' the greater the gust response - and so the more the wing bounces up and down and the greater the experienced turbulence.

Let's note first that the expression is a network. This is because, like all formalisms, it connects and defines the relations between a set of terms. Indeed, within the conventions of algebra it specifies these relations very precisely. We might add that it exists, albeit in somewhat flimsy form, in Euclidean space too, depicted on various places on paper. So far, then, we are on familiar ground. But now we need to add what is certainly an obvious comment. It is that the components or terms composed together in the formalism are not detached from everything else. They have outside connections. Indeed, if they didn't, the formalism would be (as they say) 'idle'. So what are those connections?

' $G$ ', as we've noted, stands for gust response. ' $M$ ' stands for velocity, here counted in terms of Mach numbers ( $M=1$ is the speed of sound). 'at' is transonic lift slope. That is, it is the extent to which the lifting propensity of the wing changes as the angle at which it cuts through the air changes at around the speed of sound. (To a first approximation, and within certain limits, the greater the angle the greater the lift given by a wing.) ' $\mathrm{W}$ ' is the weight of the aircraft. And ' $\mathrm{S}$ ' is the wing area.

What does all this mean in non-algebraic terms? The answer is that we are being told that aircraft bump up and down more: if they fly faster; if lift curve slope is high; if the wing is large; and if the weight of the aircraft is small. But why is this important? The quick answer is that bumping up and down is best minimised. Pilots (not to mention aircraft and passengers, though in the present case the formalism was being applied to a military rather than passenger aircraft) can only take so much banging about before they start getting into trouble. If gust response gets too large then pilots become nauseous, and may find it difficult or impossible to control the aircraft. If things get worse their vision may be impaired and they may get injured or black out. And, in extreme cases (though probably beyond the limits endurable by pilots) the aircraft itself breaks up. So the problem being faced by the designers was how to keep ' $G$ ' within acceptable limits. And this is the reason they created the formalism. It is a

\footnotetext{
${ }^{25}$ English Electric/Short Bros. internal document: (1958: 2.1.9.)

${ }^{26}$ The case is more extensively discussed in a somewhat different idiom in John Law's writing. See Law (2001a) and (2001b).
} 
way of modelling the factors that might affect gust response.

So the expression takes us beyond itself. It has other connections. In order to establish the significance of each of its terms, and indeed to establish the best wing design, it is necessary to go beyond the page. Indeed, it is necessary to go elsewhere. It is necessary to go to places that are absent from the page. Places which are therefore, or so we want to suggest, Other to the presence of the sheet of paper and its symbols ${ }^{27}$.

To see the significance of this, let's make the argument empirically. How do the aerodynamicists know what figure for ' $G$ ' is acceptable and what is not? This is not a theoretical calculation. The answer is that some brave and/or unfortunate pilots have flown very fast and very low in very unsuitable aircraft (gusts are worse at low altitude because air is denser, so what they did, in part, was to fly fast and low in aircraft intended for operation at high altitude). They have, indeed, tried to fly aircraft while vomiting. So far as we know no one died in these experiments, but the pilots certainly climbed shaking and choking from their cockpits at the end of many of these flights, and not infrequently they complained of blurred vision. Not pleasant. But what to make of it?

Our answer is to say that we are not simply dealing with one part of a materially heterogeneous (actor) network. For putting it this way loses sight of the fact that the enactment is a complex association between that which is present in the expression and that which is not. In short, it loses sight of Otherness ${ }^{28}$. And, as a part of this, it loses sight of the irreducible discontinuity between what appears on the paper and what does not.

Look at it. Present is a figure for tolerable ' $G$ '. It is there, on the paper. But that figure depends precisely upon what is absent - a sickened and frightened pilot. Depends upon that which is absent (so it is present) but (in an additional twist) at the same time depends upon making it absent: because there is certainly no room for a pilot and his vomit in the network of relations pencilled onto on a sheet of paper by an aerodynamicist in a clean office. And it is this pattern (we might think of it as an oscillation or a flickering between present-presence and absent-presence, though perhaps this gives too much away to time) which is the key to what is distinctive about the enactment of this object, the key to giving it a relatively stable and determinate shape. ' $G$ ' in the expression achieves its significance, in part because of that flickering, the both/and movement between two impossible alternatives: that the pilot is absent; and that the pilot is present. This part of the formalism achieves its creativity by moving elsewhere - and then returning. Or sustaining a relation of simultaneous presence and absence.

And this is not some peculiarity to do with ' $G$ '. The other components of the formalism work in a similar way. For instance, ' $M$ ', speed, is constrained by the need

\footnotetext{
${ }^{27}$ This, and the sense of our argument about the spatiality of fire or indeed fluidity, can perhaps be extracted from actor-network theory is we attend to the importance attached to the notion of 'translation' - where the argument is that any translation is, at the same time, a betrayal: similarity implies difference.

${ }^{28}$ This point as a comment on the character of actor-network theory was first made by Nick Lee and Steve Brown. See their (1994).
} 
to fly fast. But why is there a need to fly fast? Why does ' $M$ ' need to equal or exceed the value of 1 ? The answer is strategic, and it has to do with Russian military capabilities, real or imagined. And the basic point is simple: if the aircraft flies at less than about Mach 1 then (or so it is believed) it will be destroyed by Russian missiles. All of which means that the list of conjoined Others, those that are both absent (they could not be there on the sheet of paper) and present (they have to be there) now include the USSR and its missiles, as well as the pilots and their nausea.

Analogous arguments apply to the other components of the formalism. For instance, it turns out that ' $\mathrm{W}$ ', weight leads into the realm of bureaucratic politics (how big to make the aircraft), ' $\mathrm{S}$ ', size of the wing, to the Russians (the need for short take-off from camouflaged airstrips), and transonic lift slope, 'at', not only to high speeds (and so to the Russians) but also aerodynamic wind tunnels (how does a wing behave in practice? $)^{29}$. So all the terms of the expression achieve their stability by virtue of the simultaneous absence and presence of a range of other materials, situations. They achieve their stability in the continued enactment of discontinuities (which are also continuities) with those Other materials and contexts. And what is the case for components of the expression also applies to the expression as a whole. It is held in shape and given constancy as a result of the discontinuities of conjoined alterity. Thus the formalism indeed takes the form of a flickering star pattern ${ }^{30}$. Though this is not one's first association, it nevertheless has exactly the shape of the reverie as described by Bachelard. Multiple alterities are conjoined to a centred presence. There is indeed a going out and a coming back. What one might think of as a structure of Otherness is being enacted while the formalism holds. Irreducible entities and the worlds within which they are located are held together - and apart - while the fire-shape holds itself in place.

\section{Spatialities of Globality}

The old idea was that scientific truth was more than global, it was universal. Once it was established then it was like God: everywhere without any need to move. But in the last thirty years science has been brought down to earth. Technoscience studies have given it a place on earth. A place, for instance, in the laboratory. In the first stages of this work, science was regionalised.

At the very moment science was regionalised a new problem arose: how does it spread? how does it get transported? Echoing a common contemporary trope, the first prominent answer to this question was to talk of networks. Technoscience moved, or so it was argued, down narrow networks. Transport was no longer cost-free. It took effort. And the effort it took was not simply that of movement. It was also a matter of control. Technoscience findings were only transportable if the apparatus that produced them, social and technical, also went with them. This, then, was a second expression of the network metaphor. The heterogeneous configuration of people and devices that make up a laboratory - this also had to be transported. Which led to the notion of the immutable mobile: that which moves through regional space while

\footnotetext{
${ }^{29}$ The details are available in the literature.

${ }^{30}$ We want, in particular, to retain the possibility of imagining the less constrained, and perhaps nonstar-like, topological implications of bush fires.
} 
holding its shape. In this way, then, 'the global' was understood as a network for transporting invariant shapes: information, scientific findings, technological artefacts. A new form of the spatial was born.

Like everything else, this metaphor for the spatial also has its disadvantages. Too often - not always - it became functionalist. The focus was on control: on the work needed to hold a configuration stable; on the effort required to create a wider network fit for the transmission of immutable mobiles. But there is another problem: it is, quite simply, that often enough ideas, facts, information, even technologies, turn out to spread in a manner that is much more fluid. It is precisely a lack of rigidity that most helps movement. Here, then, there is a third spatial metaphor for imagining the global. We have talked here of the Zimbabwe bush pump, but examples abound. Raï music started in Algeria and as it moves to Paris it remains both similar and yet it also changes. McDonalds, frequently cited as the gold standard for global uniformity, reveals impressive variations as it moves from one site to the next ${ }^{31}$. If it is successful it is not because the formula is rigid. It is precisely because it can change shape. These, then, are displacements which depend on mutability instead of, or as well as, immutability. Understood in this way globalisation is not about networks but about fluidities. About movements that go more easily if there is less control. About things that take on the shape of their surroundings. That are adaptable.

But fluidity does not exhaust the spatial metaphors for thinking the global. In this paper we have laid out a fourth possibility: that of fire. We have suggested that shape constancy may be understood as a stable pattern of conjoined alterity in which continuity depends upon discontinuity, or presence upon absence, the movement or displacement between here and there. This spatial metaphor does not explain or even articulate globalisation. Unlike networks and fluids, it does not talk about transport through regional space. What it does, instead, is to turn universality inside out. Here, then, and paradoxically, the global is already included in the local. Not as a result of networks extending or fluids spreading: but how? Further inquiries into spaces of fire should help us to understand, to become sensitive to, the ways in which this inclusion works - or these inclusions work. A technoscience object - no doubt any other object - is global. If it is down to earth then this implies that the earth is inscribed in it. Which suggests we might explore how it includes Others: its version of the global. ${ }^{32}$

As we move from the universal to the local situating technoscience, more spatialities deserve exploration. But here, for the moment, we will stop. For this text is local. As we write it, it is in this personal computer. It is just here and nowhere else. Immutably immobile. But if you are reading it then it has moved to another location. Your desk, your library. So it is regional - but at the same time it has also been transported. If the words you are reading are more or less the same then it has been transported through a network as an immutable mobile. A journal, its subscribers, photocopying machines - all these leave its sentences unchanged. But then again, maybe, at the same time, it has become fluid. Some words have changed. It has been edited. While the circumstances in which it is read - in which you are reading it - also mean that it has been, however subtly, reconfigured in that reading. The same but also different. Which means that it is, in addition, a mutable mobile. And finally? The paper also

\footnotetext{
${ }^{31}$ For references, see Watson (1997) Schade-Poulsen (1997).

32 This may be developed in terms of a monadology. See John Law and Vicky Singleton (2000).
} 
includes the earth. For instance in the form of the tradition of technoscience studies, only partially explicit in footnotes. And then there is the language in which it has been written - that reveals and reinforces the imperialist successes of English. Or, crucially, this paper includes (but now conceals) earth in the form of the smells and the tastes of the food that was eaten while it was being written. All of these and heaven knows what else are included in a paper like this, are present in it, but also absent from it. A paper, then, this paper, exists within the space of fire - the space of conjoined alterity. Which means, finally, that it is also a mutable immobile. It is four things, located in four spaces: region, network, fluid and fire. 


\section{$\underline{\text { References }}$}

Bachelard, Gaston (1964),

The Psychoanalysis of Fire,

Boston: Beacon Press.

Castells, Manuel (1996),

The Rise of the Network Society,

Oxford: Blackwell.

de Laet, Marianne, and Annemarie Mol (2000),

'The Zimbabwe Bush Pump: Mechanics of a Fluid Technology',

Social Studies of Science, 30: 225-263.

Haraway, Donna J. (1996),

'Modest Witness: Feminist Diffractions in Science Studies',

pages 428-441 in

Peter Galison and David. J. Stamp (eds),

The Disunity of the Sciences: Boundaries, Contexts, and Power,

Stanford, California: Stanford University Press.

Haraway, Donna J. (1997),

Modest_Witness@Second_Millenium.Female_Man@_Meets_Oncomouse ${ }^{\mathrm{TM}}$ :

Feminism and Technoscience,

New York and London: Routledge.

Harvey, David (1989),

The Condition of Postmodernity: an Enquiry into the Origins of Cultural

Change,

Oxford: Blackwell.

Hetherington, Kevin (1997),

'In Place of Geometry: the Materiality of Place',

pages 183-199 in

Kevin Hetherington and Rolland Munro (eds),

Ideas of Difference: Social Spaces and the Labour of Division,

Oxford: Blackwell, Sociological Review Monograph.

Hetherington, Kevin (1999),

'Whither the World? The Presence and Absence of the Globe',

in

Laretta E. et al (ed.),

Time in the Making and Possible Futures,

Rio de Janeiro: UNESCO.

Hetherington, Kevin (2000),

'The Topology of Utopia',

in I. Cook, D. Crouch, S. Naylor, and J. Ryan (eds), 
Cultural Turns/Spatial Turns,

London: Longman.

Hetherington, Kevin, and Nick Lee (2000),

'Social Order and the Blank Figure',

Society and Space, 18: 169-184.

Ingold, Tim (1993),

'The Temporality of the Landscape',

World Archaeology, 25: 152-174.

Knorr Cetina, Karin D. (1981),

The Manufacture of Knowledge: an Essay on the Constructivist and

Contextual Nature of Science,

Oxford: Pergamon Press.

Kuhn, Thomas S (1970),

The Structure of Scientific Revolutions,

Chicago: Chicago University Press.

Lacoste, Yves (1976),

La Géographie, Ça Sert, d'Abord, à Faire la Guerre,

Paris: Maspéro.

Lash, Scott, and John Urry (1994),

Economies of Signs and Space,

London, Thousand Oaks, New Delhi: Sage.

Latour, Bruno (1987),

Science in Action: How to Follow Scientists and Engineers Through Society,

Milton Keynes: Open University Press.

Latour, Bruno (1988),

Irréductions, published with The Pasteurisation of France,

Cambridge Mass.: Harvard.

Latour, Bruno (1999),

'On Recalling ANT',

pages $15-25$ in

John Law and John Hassard (eds),

Actor Network and After,

Oxford.: Blackwell and the Sociological Review.

Latour, Bruno, and Steve Woolgar (1979),

Laboratory Life: the Social Construction of Scientific Facts,

Beverly Hills and London: Sage.

Law, John (1986),

'On the Methods of Long Distance Control: Vessels, Navigation and the 
Portuguese Route to India', pages 234-263 in

John Law (ed.),

Power, Action and Belief: a new Sociology of Knowledge? Sociological

Review Monograph, 32,

London: Routledge and Kegan Paul.

Law, John (2001a),

Aircraft Stories: Decentering the Object in Technoscience,

Durham, N.Ca.: Duke University Press.

Law, John (2001b),

'On Hidden Heterogeneities: the Design of an Aircraft', in John Law and Annemarie Mol (eds),

Complexities: Social Studies of Knowledge Practices,

Durham, North Carolina: Duke University Press.

Law, John, and John Hassard (eds) (1999),

Actor Network Theory and After,

Oxford and Keele: Blackwell and the Sociological Review.

Law, John, and Vicky Singleton (2000),

'Allegory and Its Others',

http://www.comp.lancs.ac.uk/sociology/soc051jl.html.

Lee, Nick, and Steve Brown (1994),

'Otherness and the Actor Network: the Undiscovered Continent',

American Behavioural Scientist, 36: 772-790.

Lynch, Michael (1985),

Art and Artifact in Laboratory Science: a Study of Shop Work and Shop Talk in a Research Laboratory,

London: Routledge and Kegan Paul.

Massey, Doreen (1994),

Space, Place and Gender,

Cambridge: Polity.

Mol, Annemarie (1995),

'La Topographie comme Méthode d'investigation du Savoir: de la Coexistence de Diverses Anémies',

Techniques et Culture, 25-26: 285-305.

Mol, Annemarie, and John Law (1994),

'Regions, Networks and Fluids: Anaemia and Social Topology',

Social Studies of Science, 24: 641-671.

Popper, Karl R. (1972),

Objective Knowledge: an Evolutionary Approach, 
Oxford: Oxford University Press.

Schade-Poulsen, Marc (1997),

'Which World? On the Diffusion of Algerian Raï to the West', pages 59-85 in

Karen Fog Olwig and Kirsten Hastrup (eds),

Siting Culture. The Shifting Anthropological Object, London and New York: Routledge.

Serres, Michel (1980),

Le Passage du Nord-Ouest, Hermes V,

Paris: Les Éditions de Minuit.

Shapin, Steven, and Simon Schaffer (1985),

Leviathan and the Air Pump: Hobbes, Boyle and the Experimental Life,

Princeton: Princeton University Press.

Sheller, Mimi (2000),

'From Social Networks to Social Flows: Re-thinking the Movement in Social Movements',

Department of Sociology, Lancaster University: unpublished paper.

Soja, Edward J. (1989),

Postmodern Geographies: the Reassertion of Space in Critical Social Theory, London and New York: Verso.

Strathern, Marilyn (1991),

Partial Connections,

Savage Maryland: Rowman and Littlefield.

Strathern, Marilyn (1996),

'Cutting the Network', Journal of the Royal Anthropological Institute, 2: 517-535.

Thrift, Nigel (1996),

Spatial Formations,

London, Thousand Oaks and New Delhi: Sage.

Turnbull, David (1993),

Maps are Territories, Science is an Atlas,

Chicago: Chicago University Press.

Turnbull, David (2000),

Masons, Tricksters and Cartographers: Comparative Studies in the Sociology of Scientific and Indigenous Knowledge, Amsterdam: Harwood Academic Publishers.

Urry, John (2000),

'Time, Complexity and the Global', 
Department of Sociology, Lancaster University: paper presented to the British Sociological Association Annual Meeting.

Verran, Helen (1998),

'Re-Imagining Land Ownership in Australia', Postcolonial Studies, 1: 237-254.

Watson, James L. (ed.) (1997),

Golden Arches East. McDonalds in East Asia, Stanford, Ca.: Stanford University Press. 